Historic, Archive Document

Do not assume content reflects current scientific knowledge, policies, or practices. 



\section{Prices subject to change}

APPIES

Fach

Per

Doz.

2 to $3 \mathrm{ft}, 1$ year old.......\$.25

3 to 4 ft., I year old...........3.

4 to 5 ft., 2 yeal olo....... . 50

PEACHES, 1 Jr. and June Buds

2 to 3 it., 1 year $010 \ldots \ldots \ldots \ldots$ 年 .25

4 to $6 \mathrm{ft}$, , 2 year $01 \mathrm{~d} \ldots . . . .5 .50$

\section{PEARS}

3 to $1 \mathrm{ft}, 1$ year old.........50

5 to $6 \mathrm{ft}$, , 2 year old........ 80

CHERRIFS

3 to 4 ft., 1 year old....... .50

4 to 6 ft., 2 year 01 a........... 00

$\$ 2.50$

3.50

5.00
Per

100

क.

30.0

35.0
Per

1000

$\$ 100.00$

150.00

300.0

\section{PLUMS}

3 to 4 ft., 1 year old.........40 5.00

4 to 6 ft., 2 year 010....... .5. 7.50

QUINCES

3 to $4 f t ., 2$ year old....... .50 6.50

APRTCONS and NECTARINES

3 to 4 ft., 2 year 01 ........ .40 5.00

\section{MULBERRIES}

3 to 4 ft., 2 year old.............. 35.00

4 to 5 ft., 2 year old....... .50 5.00

NUT BEARING TREES

Almonds, 3 to $4 \mathrm{ft}, \ldots . . . . . .9 .75 \quad 9.00$

Black Halnut, 2 to $3 \mathrm{ft}, \ldots . . .50 .5 .00$

Eng. Walnut, 2 to $3 \mathrm{ft}, \ldots . . .75$ 6.... 60

Japan Walnut, 2 to 3 ft.......50 . 6.00

Am. Swt. Chestiut, 3 to $4 \mathrm{ft}, \ldots .50 \cdots 5.00$

Japan Chestnut, 3 to $4 \mathrm{ft} . . .$. . 75 ' 8.00

Spanish Chostnit, 3 to 4 it.,. .75 6.00

Pecan Pap.Shell, 2 to $3 \mathrm{ft.}, . .1 .25$ 12.00

Pecan Pap. Shel1, 3 to 4 ft.,... 1.50 15.00

\section{FIGS}

2 to 4 ft., 1 year old.........75 7.50

18 to 24 in............................ 50 


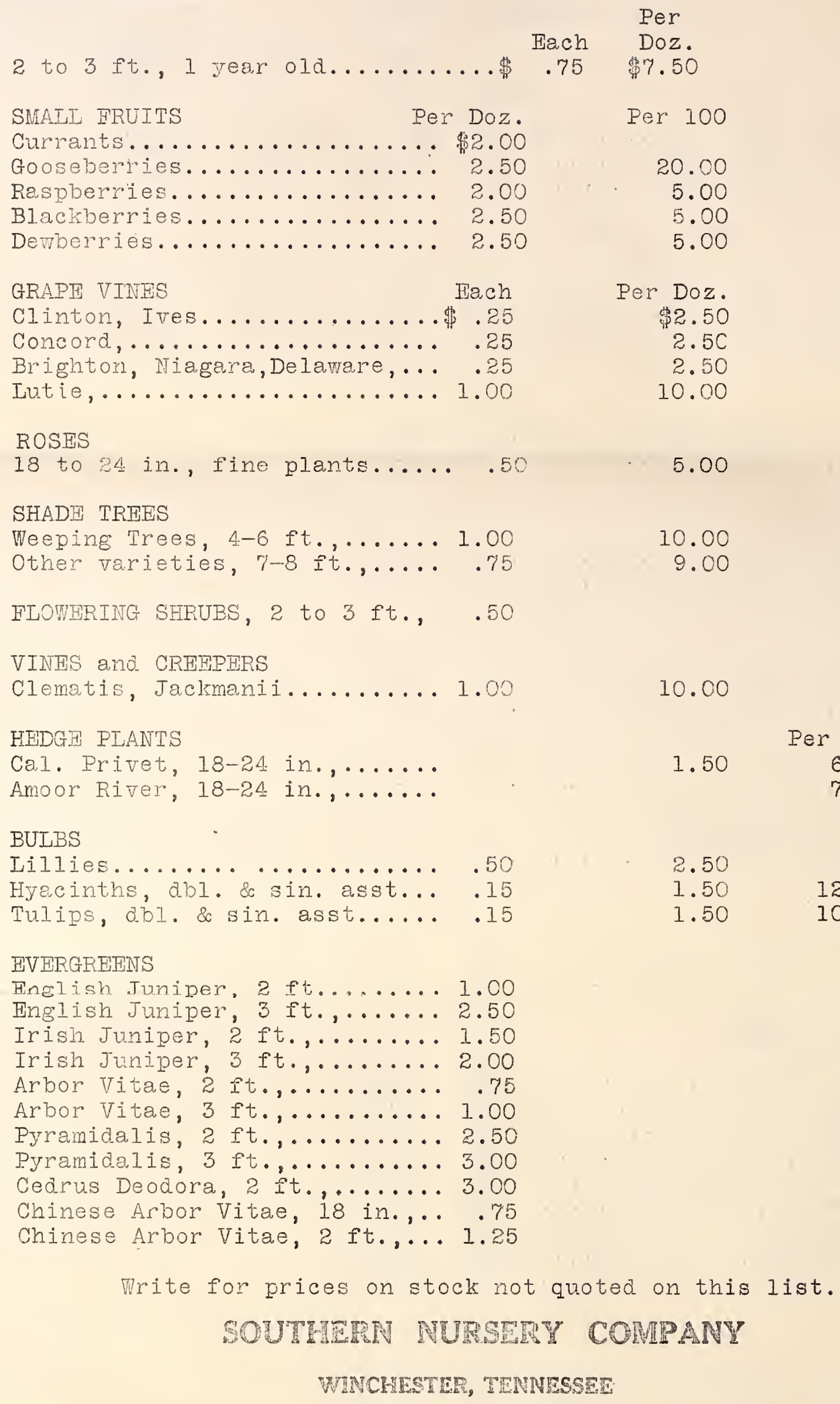

Write for prices on stock not quoted on this list. 